\title{
MITOTIC AND MEIOTIC STUDIES ON TWO SPECIES OF OCIMUM (LAMIACEAE) AND THEIR F 1 HYBRIDS
}

\author{
Johnson Ademola Idowu, Matthew OzIEgbe* \\ Obafemi Awolowo University, Department of Botany, Ile-Ife, Nigeria \\ *Corresponding author. E-mail: oziegbem@oauife.edu.ng
}

\begin{abstract}
Idowu J.A., Oziegbe M., 2017: Mitotic and meiotic studies on two species of Ocimum (Lamiaceae) and their $\mathrm{F}_{1}$ hybrids [Dviejų Ocimum (Lamiaceae) rūšių ir jų $\mathrm{F}_{1}$ hibridų mitozès ir mejozès tyrimai]. - Bot. Lith., 23(1): 59-67.

Ocimum L. species are important aromatic and medicinal plants. Many researchers have observed complexity in their chromosome numbers and ploidy levels. We studied the somatic and germline chromosomal features and behaviour of Ocimum basilicum L., two variants of $O$. canum Sims ('c,' and ' $\mathrm{c}_{2}$ ') and their $\mathrm{F}_{1}$ hybrids. Chromosomes from root tips and flower buds were investigated using standard techniques; karyograms were formed and analysed. A chromosome number of $2 \mathrm{n}=4 \mathrm{x}=52$ was observed in O. basilicum and $O$. canum ' $\mathrm{c}_{1}$ ' and their $\mathrm{F}_{1}$ hybrid. One of the variants, $O$. canum ' $\mathrm{c}_{2}$ ' had a chromosome number of $2 \mathrm{n}=2 \mathrm{x}=24$ and its intraspecific hybrid $O$. canum ' $c_{2}$ ' $\times O$. canum ' $c_{1}$ ' had a chromosome number of $2 \mathrm{n}=38$. These Ocimum species and their $F_{1}$ hybrids showed different karyotype formula, but their chromosomes were mostly metacentric (174) and submetacentric (36) with few subtelocentric (8). Based on pairing configuration, O. basilicum is an allotetraploid plant, $O$. canum ' $\mathrm{c}_{1}$ ' is an autotetraploid plant and the $O$. canum ' $\mathrm{c}_{1}$ ' is a diploid. The $\mathrm{F}_{1}$ hybrids showed higher frequency of meiotic abnormalities than the parents. The study showed intraspecific and interspecific variation in chromosome numbers and pairing patterns, but the chromosomes of the Ocimum species were similar in their centromeric positions.
\end{abstract}

Keywords: centromeric index, chromosome, homology, karyotype, ploidy, sterility.

\section{INTRODUCTION}

The genus Ocimum L. is one of the most popular herbs in the world owing to its economical and medicinal values. It belongs to the mint family (Lamiaceae) in the order Lamiales and is widely distributed across the tropical regions of Asia, Africa, Central and South America (PAton et al., 1999). The genus comprises of 30 (PATON, 1992) to 160 (PushPANGADAN \& BRADU, 1995) species with great morphological diversities within the species (PUSHPANGADAN \& Bradu, 1995). Bentham's (1848) infrageneric classification of Ocimum is based on stamen and calyx morphology while SoBtI \& PUSHPANGADAN (1977) classification is based on chromosome number, habit and seed morphology. The evidence from several cy- tological studies on Ocimum reveals diverse chromosome numbers, which is an addition to its taxonomic challenges. Studies have shown that more than two basic chromosome numbers exist in the genus, expanding the previous SoBTI \& PUSHPANGADAN (1977) classification of the genus into basic groups: the Basilicum and Sanctum with a basic chromosome numbers of 12 and 8, respectively (DARLINGTON \& Wylie, 1955; Mehra \& Gill, 1972; Panda, 2005; Carovic-Stanko et al., 2010). For instance, chromosome numbers of $2 n=32,2 n=36$ and $2 n=76$ have been reported for $O$. tenuiflorum $\mathrm{L}$. with basic number of eight (MuKHERJEE et al., 2005). However, a basic chromosome number of 12 are predominant in the Basilicum group, which includes the species O. americanum L. (O. canum Sims.) $(2 \mathrm{n}=24,26$ 
and 72$), O$. basilicum L. $(2 \mathrm{n}=48)$ and $O$. kilimandscharicum Guerke $(2 \mathrm{n}=76)$, etc. (SoBTI \& PushPanGADAN, 1977; MuKHERJEE \& DATTA, 2006). Infrageneric classification made by PATON et al. (1999) is the presently accepted infrageneric structuring of the genus, based on parsimony analysis of the morphological variations of the genus and close relatives. This classification divides the genus into three subgenera, namely: Ocimum (comprises of sections $\mathrm{Oci}$ mum, Gratissima and Hiantia Benth.), Gymnocimum (comprises of sections Gymnocimum Benth. and $\mathrm{Hi}$ erocymum Benth.) and Nautochilus.

The study of the karyotype and pairing behaviour of chromosomes of some polyploid Ocimum species showed that length of chromosomes and gross appearance of the karyotype revealed a general resemblance in all the species investigated, but the variations were noticed in chromosome number as well as in the type of chromosomes, although the chromosomes were multiple of $x=8$ with regular anaphase segregation, mainly bivalents with few univalent and no multivalent (Khosla \& Sobti, 1985; Khosla, 1989). Khosla (1988) has observed an abnormal chromosomal behaviour in meiosis with high sterility in hybrid of $O$. viride Willd. $(2 \mathrm{n}=40)$ and $O$. suave Willd. $(2 \mathrm{n}=48)$. VIJ \& KASHYAP (1976) have counted $2 \mathrm{n}=64$ for O. americanum collected from North India, while RYDING (1994) has counted a chromosome number of $2 n=4 \times=48$ for $O$. americanum var. pilosum. Also chromosome count of $2 \mathrm{n}=24,26,72$ and 84 has been reported in O. americanum L. (SINGH, reported in LöVE, 1980). Morton (1962) has observed $2 \mathrm{n}=72$ for $O$. canum collected from North India. Two cytotypes of $O . c a-$ num $2 \mathrm{n}=24$ type (introduced from Kenya) and $2 \mathrm{n}=26$ type (growing in South India) have been reported by Pushpangadan \& Sobti (1982). Mukherjee \& Datta (2006) have also counted $2 \mathrm{n}=26$ for $O$. canum Sims. PushPANGADAN \& SobTi (1982) have reported a chromosome number of $2 \mathrm{n}=48$ for $O$. basilicum growing in west India. PAton \& PutievsKy (1996) have counted different chromosome numbers of $2 \mathrm{n}=64,72,74$ and 76 for $O$. basilicum. A chromosome count of $2 \mathrm{n}=$ 52 for $O$. basilicum var. crispum has been reported by MukHERJEe et al. (2005). EdET \& AiKPOKPODION (2014) have reported chromosome counts of $2 n=48$ and 60 for $O$. bacilicum with asymmetrical karyotypes for both cytotypes from South-Easthern Nigeria. KHosLA $\&$ Sobti (1985), Albuquerque \& ANdRAde (1998) and
CARovic-Stanko et al. (2010) have stated that chromosome set in Ocimum species consist of predominantly metacentric, submetacentric and some subtelocentric chromosomes. TRUTA \& ZAMFIRACHE (2013) have observed that Ocimum chromosomes are small in size with their length between $0.80 \mu \mathrm{m}$ and $3.00 \mu \mathrm{m}$ and polyploids of Ocimum species have much smaller chromosomes compared to their diploids. ARCHNA et al. (2013) have reported primitive status of $O$. sanctum and $O$. basilicum based on the observation of high centromeric index, which ranges from 40.94 to 44.05 , and according to KHOSLA \& SoBTI (1985) it is ranging from 33.33 to 50.00 across the species of Ocimum studied.

The occurrence of interspecific hybridization and polyploidy in the genus Ocimum create taxonomic confusion and make difficult the understanding of genetic relationship among basil species (ERUM et al., 2011). Preliminary cytogenetic and hybridization studies were conducted on two Ocimum species (one variant of $O$. basilicum and two variants of $O$. canum). Partial fertility was observed in the $\mathrm{F}_{1}$ hybrid of $O$. basilicum $\times O$. canum ' $\mathrm{c}_{1}$ ', whereas high sterility was reported in the $\mathrm{F}_{1}$ hybrid of $O$. canum ' $\mathrm{c}_{2}$ ' $\times$ $O$. canum 'c ', The cross between $O$. basilicum and O. canum ' $\mathrm{c}_{2}$ ' failed. Cytogenetic studies on the factors responsible for partial fertility and high sterility of the $\mathrm{F}_{1}$ hybrids reported in the preliminary studies are unknown. This study compared mitotic chromosome number, karyological similarities and differences, and also investigated the meiotic chromosome behaviour of $O$. basilicum, O. canum ' $\mathrm{c}_{1}$ ' O. canum ' $\mathrm{c}_{2}$ ' and their $\mathrm{F}_{1}$ hybrids $(O$. basilicum $\times O$. canum 'c $\mathrm{c}_{1}$ ' and $O$. canum ' $\mathrm{c}_{2}$ ' $\times$ O. canum ' $\mathrm{c}_{1}$ ').

\section{MATERIALS AND METHODS}

Collection and cultivation. The study was conducted at the Department of Botany of Obafemi Awolowo University, Ile-Ife. Seeds were collected from parental lines that grow in Nigeria (Ile-ife and Iloko-Ijesha in Osun state; Ibore Uneah, Esan central, Edo state). The parental lines were coded with varietal names (not yet published) as: $O$. basilicum (white style), O. canum 'c ${ }_{1}$ ' (light pink style) $O . c a$ num ' $\mathrm{c}_{2}$ ' (deep pink style), and their $\mathrm{F}_{1}$ hybrid seeds (O. basilicum $\times O$. canum ' $\mathrm{c}_{1}$ ' and $O$. canum ' $\mathrm{c}_{2}$ ' $\times$ $O$. canum ' $\mathrm{c}_{1}$ '). Each of the parents was grown by 
seeding for five generations at the Botanical Garden of Obafemi Awolowo University through autogamy of isolated flowers before hybridization was carried out. The Ocimum species used were observed to be annuals. The $F_{1}$ hybrid seeds and the parent seeds were grown on a separate moistened filter paper in Petri-dishes at room temperature in the laboratory. Three weeks after germination, seedlings were transplanted into 7-litre plastic bucket filled with topsoil at the rate of one plant per bucket with five replicates for each parent and the $F_{1}$ hybrids. Voucher specimens of each parent and hybrid used were deposited at the IFE Herbarium of Obafemi Awolowo University, Ile-Ife.

Pollen fertility and seed set. Pollen fertility was determined by staining the pollen grains from just dehisced anthers in the parents and the $\mathrm{F}_{1}$ hybrids with cotton blue in lacto phenol for 48 hours. The full pollen grains with the cytoplasm contents stained uniformly blue were counted as viable pollens, while those without or partially stained and with collapsed outline were considered as non-viable (OlORODE \& BAQUAR, 1976). The percentage of pollen fertility was determined. The parents and their hybrids were allowed to produce seeds through spontaneous selfpollination by preventing foreign pollen on the flowers. The percentage of seed (nutlet) set was determined by dividing the obtained seeds by the expected seeds (i.e the number of flowers on a panicle was multiplied by four) multiplied by 100 . The percentage of pollen fertility and seed set were evaluated on five plants from each parent and their hybrid. Forty flowers were evaluated per plant.

Mitotic chromosome studies. Root tips from five plants in each parent and the hybrid were grown from young stem cuttings placed in plastic bottles containing water and were harvested from 9 am to $11 \mathrm{am}$, when mitotic activities are believed to be high. The harvested root tips were pre-treated in a solution of $0.002 \mathrm{M} 8$-hydroxyquinoline for 3 hours at room temperature, washed in distilled water, fixed in freshly prepared fixative (acetic acid: absolute ethanol v/v (1:3)) for at least 24 hours. Root tips were macerated in 18\% hydrochloric acid for 10 minutes, squashed and stained for 5 minutes with FLP-Orcein (Olorode, 1974). Mitotic spreads of metaphase stage were photomicrographed at $\times 1000$ magnification under oil immersion and phase contrast illumination us- ing Amscope MT microscope camera version 3.0.0.1 attached to light microscope. For karyotypic description, chromosomes were classified into groups on the basis of centromere position (median, sub-median, sub-terminal) (LEVAN et al., 1964) and arranged in the order of decreasing size. Average chromosome counts and measurements were calculated from 10 metaphase plates from five plants for each parent and the $\mathrm{F}_{1}$ hybrids. The short arm length, long arm length, arm ratio (long arm length/short arm length), centromeric index, longest/shortest chromosome ratio and proportion of chromosome pairs with arm ratio greater than two were determined from the measurements. The chromosome karyotypes were further classified into Stebbins category (StEBBINS, 1971). One way analysis of variance was used to analyse quantitative data and means were separated using Duncan's multiple range test.

Meiotic chromosome studies: Meiotic chromosomes of parents and their $\mathrm{F}_{1}$ hybrids were investigated using young flower buds harvested at the appropriate stage and fixed in freshly prepared fixative (acetic acid: absolute ethanol v/v (1:3)) for at least 24 hours at room temperature, transferred into $70 \%$ ethanol and stored under refrigeration. Slides were prepared using the standard techniques of squashing and the anthers were stained for 5 minutes using FLP-Orcein. Fifty pollen mother cells of five plants were evaluated for each parent and the $F_{1}$ hybrids. They were examined to investigate meiotic behaviour at diakinesis, metaphase I/II, anaphase I/II and telophase I/II. The frequency of meiotic abnormalities such as stickiness, precocious movement, laggards and bridges as well as irregular chromosomal disjunction noticed was recorded. Well stained chromosomes that indicated meiotic chromosome behaviour and structure were photomicrographed.

\section{RESULTS}

\section{Karyomorphological studies}

Chromosome number of $O$. basilicum $(2 \mathrm{n}=52)$ differed from $O$. canum ' $\mathrm{c}^{2}$ ' $(2 \mathrm{n}=24)$, but was the same with $O$. canum ' $\mathrm{c}_{1}$ ' $(2 \mathrm{n}=52)$ (Fig. $1 \mathrm{~A}-\mathrm{C}$ and Table 1). The hybrid O. basilicum $\times O$. canum ' $\mathrm{c}_{1}$ ' had the same chromosome number of $2 \mathrm{n}=52$ with its parent (Fig 1D and Table 1), while the hybrid $O . c a$ num ' $\mathrm{c}_{2}$ ' $\times$ O. canum ' $\mathrm{c}_{1}$ ' had a chromosome number 
of $2 \mathrm{n}=38$ (Fig. 1E and Table 1). Variation existed among the parents and hybrids with respect to their karyotype formula as shown in Table 1. However, the chromosomes were mostly metacentric (174), submetacentric (36) and few chromosomes were subtelocentric (8). Chromosome type composition of medium-sized chromosomes was similar across the parents and the hybrids (Table 1). Mean chromosome length and total chromosome length (haploid set) varied significantly among the three parents and between the hybrids (Table 1). Centromeric Index (CI) ranged from $41.35 \pm 1.79$ in the $O$. basilicum $\times$ O. canum 'c c' to $45.55 \pm 1.56$ in O. basilicum (Table 1). Karyotype asymmetry was the same in the parents $\left(O\right.$. basilicum and $O$. canum ' $\mathrm{c}_{1}$ ') with $2 \mathrm{~B}$, indicating symmetric karyotype, while $O$. canum ' $\mathrm{c}_{2}$ ', had $1 \mathrm{~A}$, which indicated highly symmetric karyotype (highly primitive than other parents).

\section{Meiotic studies}

Ocimum basilicum had 26II at metaphase I (Fig. 2A). Subsequent stages such as telophase I/II were observed to be normal in most of the cells (Fig. 2B and 2C) and meiotic abnormalities such as non-disjunction at one pole were occasionally observed (Fig. 2D). Ocimum canum ' $\mathrm{c}_{1}$ ' had predominantly $12 \mathrm{IV}+2 \mathrm{II}$ at metaphase I (Fig. 2E), normal meiotic cells at telophase II (Fig. 2H) and chromosomal aberrations such as stickiness, precocious movement, lagging of chromosomes at anaphase I/II with late disjunction at telophase II to form triad (Fig. $2 \mathrm{~F}$ and $2 \mathrm{G}$ ). Ocimum canum ' $\mathrm{c}_{2}$ ' had predominantly $11 \mathrm{II}+2 \mathrm{I}$ at metaphase I (Fig. 2I).
Chromosomal aberrations observed in the meiotic cells are shown in Fig. 2J and 2K; normal meiotic cells observed are shown in Fig. 2L. The $\mathrm{F}_{1}$ hybrid $O . b a-$ silicum $\times O$. canum ' $\mathrm{c}_{1}$ ' had $26 \mathrm{II}$ mostly at diakinesis (Fig. 2M) and proper synapsis with a rare occurrence of univalent. Chromosomal aberrations observed are shown in Fig. 2N, $2 \mathrm{O}$ and $2 \mathrm{P}$. The $\mathrm{F}_{1}$ hybrid $O$. canum ' $\mathrm{c}_{2}$ ' $\times$ O. canum ' $\mathrm{c}_{1}$ ' had $19 \mathrm{II}$ mostly at metaphase I (Fig. 2Q). Some cells had limited synapsis with two or four univalents observed as 20 or 21 elements in the cells, denoting $18 \mathrm{II}+2 \mathrm{I}$ or $17 \mathrm{II}+4 \mathrm{I}$, respectively. Normal meiotic cells and chromosomal aberrations observed are shown in Fig. 2R, $2 \mathrm{~S}$ and $2 \mathrm{~T}$. The results indicated that meiotic abnormalities in all parents occurred at low frequency $(3.89 \%$ in $O$. basilicum, $7.62 \%$ in $O$. canum ' $\mathrm{c}_{1}$ '), but at a much higher frequencies in the $\mathrm{F}_{1}$ hybrids $(17.47 \%$ in hybrid $O$. basilicum $\times$ O. canum ' $\mathrm{c}_{1}$ ' and $63.60 \%$ in hybrid $O$. canum ' $\mathrm{c}_{2}$ ' $\times$ O. canum ' $\mathrm{c}_{1}$ ') (Table 2$)$.

\section{DISCUSSION}

Mitotic chromosome studies. The difference in chromosome numbers between $O$. canum ' $\mathrm{c}_{2}$ ' and $O$. canum ' $\mathrm{c}_{1}$ ' observed in this study indicated intraspecific variation at ploidy level and basic chromosome number. This report corroborates the findings of MukHERJEE et al. (2005) in O. basilicum var. crispum, Pushrangadan \& Sobti (1982) in two cytotypes of $O$. canum from Kenya and South India, MukHERJeE \& DatTa (2006) in O. canum, but in discord with the report of PAton \& Putievsky (1996) in

Table 1. Summary of karyomorphological features of the Ocimum species and their $\mathrm{F}_{1}$ hybrids

\begin{tabular}{|c|c|c|c|c|c|c|}
\hline Species & $\begin{array}{l}\text { Chromosome number } \\
\text { (karyotype formula) }\end{array}$ & $\begin{array}{l}\text { Mean } \\
\text { chromosome } \\
\text { length }(\mu \mathrm{m})^{*}\end{array}$ & $\begin{array}{c}\text { Total } \\
\text { chromosome } \\
\text { length }(\mu \mathrm{m})^{*}\end{array}$ & $\begin{array}{c}\text { Chromosome } \\
\text { type } \\
\text { composition }\end{array}$ & $\begin{array}{l}\text { Centromeric } \\
\text { index }(\mathrm{CI})^{*}\end{array}$ & $\begin{array}{l}\text { Karyotype } \\
\text { asymmetric } \\
\text { type }\end{array}$ \\
\hline O. basilicum & $2 n=52(46 m+4 s m+2 s t)$ & $1.31 \pm 0.05^{b}$ & $34.02 \pm 0.16^{\mathrm{d}}$ & $46 B+6 C$ & $45.55 \pm 1.56^{b}$ & $2 \mathrm{~B}$ \\
\hline O. canum 'c c' $_{1}$ & $2 n=52(36 m+16 s m)$ & $1.06 \pm 0.05^{\mathrm{a}}$ & $27.63 \pm 0.21^{b}$ & $28 B+24 C$ & $44.44 \pm 1.13^{b}$ & $2 \mathrm{~B}$ \\
\hline O. canum ' $\mathrm{c}_{2}$ ' & $2 n=24(16 m+8 s m)$ & $1.96 \pm 0.08^{\mathrm{c}}$ & $23.50 \pm 0.16^{\mathrm{a}}$ & $10 \mathrm{~A}+14 \mathrm{~B}$ & $43.72 \pm 1.31^{\mathrm{ab}}$ & $1 \mathrm{~A}$ \\
\hline $\begin{array}{l}\text { O. basilicum } \times \\
\text { O. canum 'c }{ }_{1} \text { ', }\end{array}$ & $2 n=52(40 m+6 s m+6 s t)$ & $1.10 \pm 0.04^{\mathrm{a}}$ & $28.58 \pm 0.19^{\mathrm{c}}$ & $30 B+22 C$ & $41.35 \pm 1.79^{\mathrm{a}}$ & $2 \mathrm{~A}$ \\
\hline $\begin{array}{l}\text { O. canum ' }{ }^{\prime}{ }^{\prime} \text { ' } \times \\
\text { O. canum 'c }{ }^{2} \text { ', }\end{array}$ & $2 n=38(34 m+4 s m)$ & $1.42 \pm 0.08^{b}$ & $26.91 \pm 0.20^{\mathrm{b}}$ & $36 \mathrm{~B}+2 \mathrm{C}$ & $43.73 \pm 0.90^{\mathrm{ab}}$ & $2 \mathrm{~B}$ \\
\hline
\end{tabular}

Means were compared using Duncan's multiple range test. Values in the same column followed by the same letter are not significantly different at $p=0.05 ; * \pm-$ standard error; centromeric position: $\mathrm{m}$ (median) $=$ arm ratio between $1.00-1.49$, sm $($ sub-median $)=$ arm ratio $1.50-2.99, \mathrm{st}($ sub-terminal $)=$ arm ratio 3.00-39.00, $\mathrm{t}($ terminal $)=$ arm ratio $>39.01$; chromosome type: $\mathrm{A}=$ chromosome length greater than $2.01 \mu \mathrm{m}$ (large), $\mathrm{B}=1.01-2.01 \mu \mathrm{m}$ (medium), $\mathrm{C}=1$ less than or equal to $1.00 \mu \mathrm{m}$ (small); $\mathrm{CI}=$ centromeric index = mean length of short arm; $\mathrm{MLL}=$ mean length of long arm; stebbins asymmetric type (degree of symmetry in karyotype): $1 \mathrm{~A}>2 \mathrm{~A}>2 \mathrm{~B}$. 
Table 2. Summary of chromosome pairing configuration, meiotic abnormality, pollen fertility and seed set of Ocimum species and their $\mathrm{F}_{1}$ hybrids

\begin{tabular}{|c|c|c|c|c|c|}
\hline Characteristics & O. basilicum & O. canum ' $\mathrm{c}_{1}$ ' & O. canum ' $\mathrm{c}_{2}$ ' & $\begin{array}{l}\text { O. basilicum } \times \\
\text { O. canum 'c }{ }^{\prime} \text { ' }\end{array}$ & $\begin{array}{l}\text { O. canum ' } \mathrm{c}^{2} \text { ' } \times \\
\text { O. canum ' } \mathrm{c}_{1} \text { ', }\end{array}$ \\
\hline Bridge at anaphase I/II & 2 & 3 & 5 & 3 & 5 \\
\hline Univalents at diakinesis /metaphase & - & - & 2 & 1 & 8 \\
\hline $\begin{array}{l}\text { Precocious movement /stickiness at } \\
\text { metaphase I/II }\end{array}$ & 4 & 7 & 7 & 50 & 145 \\
\hline Laggards at anaphase I/II & - & 4 & 2 & 7 & 12 \\
\hline Triad at telophase II & 1 & 2 & 4 & 8 & 3 \\
\hline $\begin{array}{l}\text { Pairing configuration at diakinesis/ } \\
\text { metaphase I }\end{array}$ & $26 \mathrm{II}$ & $12 \mathrm{IV}+2 \mathrm{II}$ & $11 \mathrm{II}+2 \mathrm{I}$ & $26 \mathrm{II}$ & $\begin{array}{c}18 \mathrm{II}+2 \mathrm{I} \text { or } \\
17 \mathrm{II}+4 \mathrm{I}\end{array}$ \\
\hline Meiotic abnormality, \% & 3.89 & 7.62 & 6.43 & 17.47 & 63.60 \\
\hline Pollen fertility, \% & 81.27 & 78.07 & 76.59 & 65.97 & 9.09 \\
\hline Seed set, \% & 54.25 & 49.12 & 92.30 & 63.62 & 0.33 \\
\hline
\end{tabular}
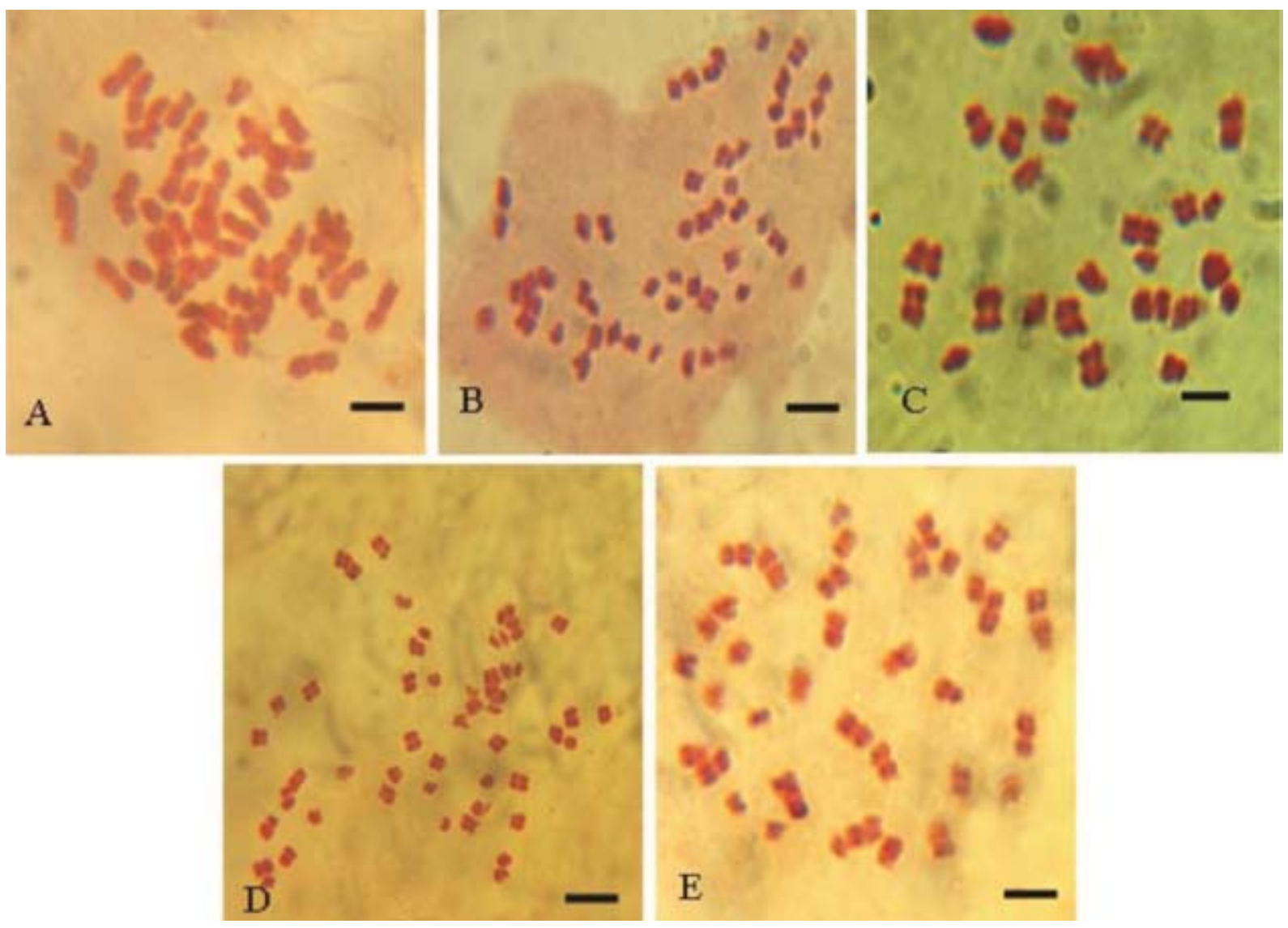

Fig. 1. Mitotic chromosome spread in the Ocimum species and their $\mathrm{F}_{1}$ hybrids.

$\mathrm{A}-O$. basilicum $(2 \mathrm{n}=52) ; \mathrm{B}-O$. canum ' $\mathrm{c}_{1}$ ' $(2 \mathrm{n}=52) ; \mathrm{C}-O$. canum ' $\mathrm{c}_{2}$ ' $(2 \mathrm{n}=24) ; \mathrm{D}-$ O. basilicum $\times$ O. canum ' $\mathrm{c}_{1}$ ' $(2 \mathrm{n}=$ 52); $\mathrm{E}-O$. canum ' $\mathrm{c}_{2}$ ' $\times$ O. canum ' $\mathrm{c}_{1}$ ' $(2 \mathrm{n}=38)$. Scale bar $=3 \mu \mathrm{m}$

O. basilicum, MORTON (1962) in O. canum collected from North India, Pushpangadan \& Sobti (1982) in $O$. basilicum growing in west India and EDET \& AikPOKPODION (2014) in O. bacilicum from South-

\section{Eastern Nigeria.}

However, different karyotype formulae were observed for each Ocimum species and their $\mathrm{F}_{1}$ hybrids. The Ocimum species are cytologically similar 


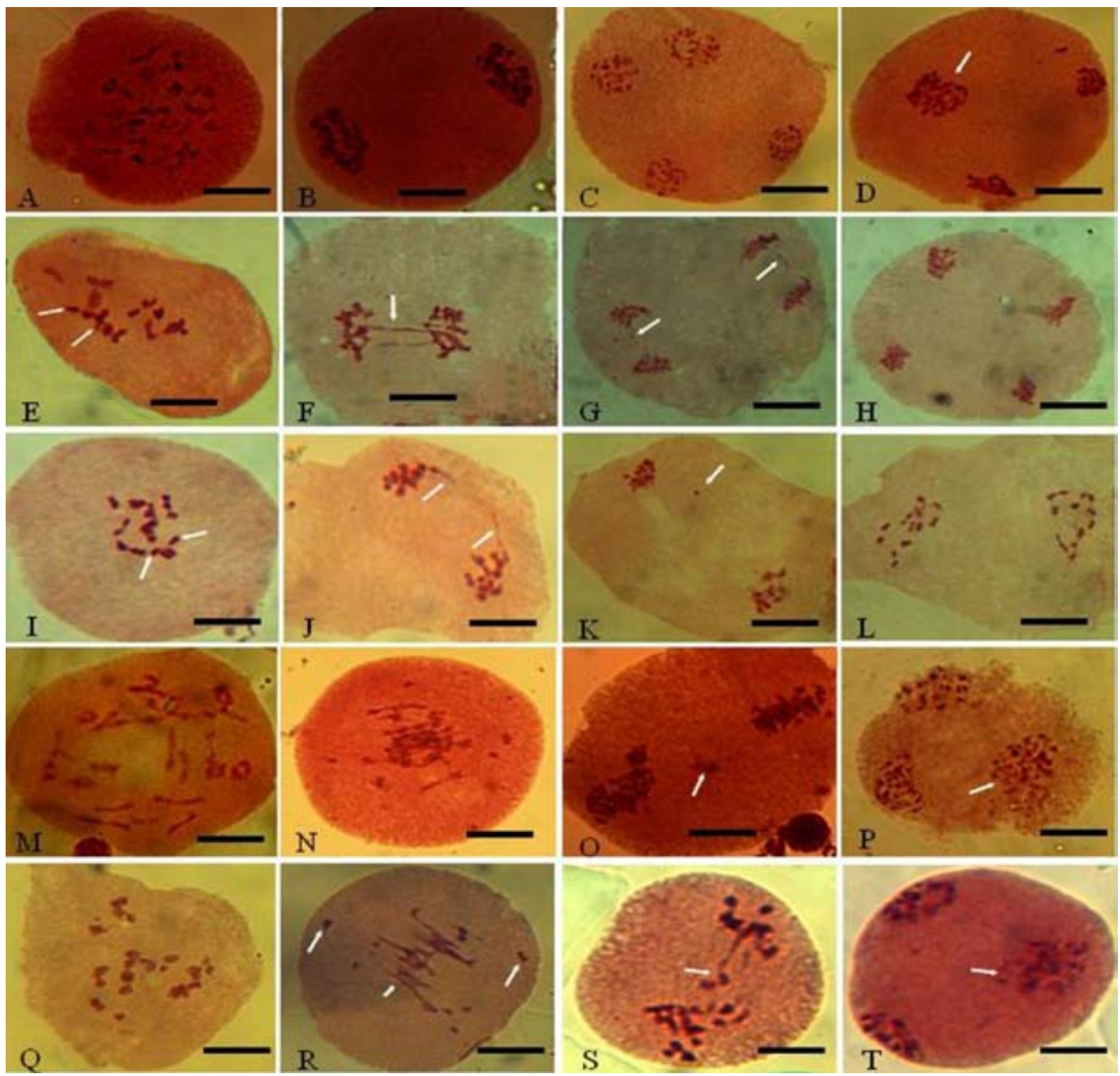

Fig. 2. Meiosis in pollen mother cells of the Ocimum species and their $\mathrm{F}_{1}$ hybrids.

O. basilicum (A-D): A - metaphase I; B - telophase I; C - telophase II (tetrad); D - telophase II (arrow indicates non-disjunction at one pole). O. canum ' $\mathrm{c}_{1}$ ' $(\mathrm{E}-\mathrm{H})$ : E - metaphase I (arrows indicate bivalents); F - anaphase I (arrow indicates bridge); G anaphase II (arrows indicate laggards); H - telophase II. O. canum 'c ' (I-L): I - metaphase I (arrows indicate two univalents); $\mathrm{J}$ - anaphase I (arrows indicate broken bridges); $\mathrm{K}$ - telophase I (arrows indicate laggard); $\mathrm{L}$ - normal metaphase II. $O$. $b a$ silicum $\times$ O. canum ' $\mathrm{c}_{1}$ ' $(\mathrm{M}-\mathrm{P}): \mathrm{M}$ - diakinesis; $\mathrm{N}$ - metaphase I with sticky chromosomes; $\mathrm{O}$ - metaphase II with multiple precocious movements (arrow); $\mathrm{P}$ - telophase II (arrow indicates non-disjunction at one pole). O. canum ' $\mathrm{c}_{2}$ ' $\times$ O. canum ' $\mathrm{c}_{1}$ ' (Q-T): Q - metaphase I; R - early anaphase I with precocious movement (long arrows) and sticky chromosomes (short arrow); $\mathrm{S}$ - anaphase I (arrow indicates laggards); $\mathrm{T}-$ telophase II (arrow indicates non-disjunction at one pole). Scale bar $=3 \mu \mathrm{m}$

in their centromeric positions. These results support previous findings of KHOSLA \& SoBTi (1985) and CARovic-Stanko et al. (2010). Chromosomal lengths of the studied Ocimum species and their $\mathrm{F}_{1}$ hybrids in this study are in agreement with previous findings of Khosla \& Sobti (1985), Khosla (1988), Truta \&
Zamfirache (2013) and Archna et al. (2013) that reported small chromosomes in the genus Ocimum. Mean chromosome lengths indicated that polyploid species are often of smaller chromosome size than the diploid, this result agrees with TRUTA \& ZAMFIRACHE (2013). The total chromosome length observed in the 
Ocimum species and their hybrids in this study is in agreement with KHOSLA \& SoBTI (1985) report on total chromosome length of Ocimum species studied, which is between $39.00 \mu \mathrm{m}$ to $70.80 \mu \mathrm{m}$.

High mean centromeric index $(\mathrm{CI})$ in the parents and $\mathrm{F}_{1}$ hybrids signify the primitiveness of these studied Ocimum plants and a high symmetric karyotype among the parents and $F_{1}$ hybrids. SINGH (1978) has reported that high centromeric index value denotes high symmetric karyotype, which is a primitive condition. This result is in accordance with the reports from previous researchers such as ARCHNA et al. (2013), Khosla \& Sobti (1985) and Khosla (1988).

Meiotic chromosome studies. The diakinesis stage in $O$. basilicum containing 26 bivalents is an indication of allotetraploidy. PushPangaDAN \& Soвті (1982) have suggested allopolyploid origin of $O$. basilicum from $O$. canum or closely related species. The higher frequency of tetravalents than bivalents in $O$. canum ' $\mathrm{c}_{1}$ indicated autotetraploidy. While the presence of 11 bivalents and two univalents observed in $O$. canum ' $\mathrm{c}_{2}$ ' $(2 \mathrm{n}=24)$ denoted diploid species. Mukherjee \& Datta (2006) have reported the formation of mostly bivalents in $\mathrm{O} . \mathrm{ca}$ num. Pushrangadan \& Sobti (1982) have suggested that $O$. canum cytotype $2 \mathrm{n}=26$ arose from cytotype $2 \mathrm{n}=24$, through an aneuploidy. Based on this report, the results of this study indicated that $O$. canum ' $\mathrm{c}_{1}$ ' might have arose from $O$. canum ' $\mathrm{c}_{2}$ ' through aneuploid increase followed by polyploidization resulting in autotetraploid plant.

The diakinesis in the $\mathrm{F}_{1}$ hybrids; $O$. basilicum $\times$ O. canum ' $\mathrm{c}_{1}$ ' showed 26 bivalents with a rare occurrence of multivalent and univalent, suggesting a high homology in the chromosome structures and chromosome number of the parents $O$. basilicum and $O . c a$ num ' $\mathrm{c}_{1}$ '. While $O$. canum ' $\mathrm{c}_{2}$ ' $\times O$. canum ' $\mathrm{c}_{1}$ ' mostly has 19 bivalents, with some cells having limited synapsis, and two or four univalents. This might be due to variation in chromosome size. High frequency of abnormalities in the course of meiosis is a major cause of low percentage of pollen viability and seed set observed in the hybrids compared to their parents with low meiotic abnormalities. As it has been previously reported by LARROSA et al. (2011) and LiU et al. (2012), any abnormality in the course of meiosis causes the formation of sterile gametes and low percentage of pollen viability, which result in decreased seed production. However, two variants of $O$. canum showed similar rates of both meiotic abnormalities and pollen fertility, but contrasting seed set. The low seed set in $O$. canum ' $\mathrm{c}_{1}$ ' might be due to the failure in self-pollination.

The $\mathrm{F}_{1}$ hybrid $O$. basilicum $\times O$. canum ' $\mathrm{c}_{1}$ ' with a low frequency of meiotic abnormalities, high pollen viability and high seed set is an indication that high homology exists between its parental genomes, which are not well differentiated from each other by effective isolating mechanisms. While $\mathrm{F}_{1}$ hybrid O. canum ' $\mathrm{c}_{2}$ ' $\times$ O. canum ' $\mathrm{c}_{1}$ ' with high frequency of meiotic abnormalities, low pollen viability and very low seed set suggest an effective isolating mechanisms between its parents as revealed by different ploidy levels of the parents $\left(O\right.$. canum ' $^{2} \mathrm{c}_{2}$ ' is a diploid and O. canum ' $\mathrm{c}_{1}$ ' is an autotetraploid).

\section{CONCLUSION}

Ocimum basilicum and $O$. canum 'c ${ }_{1}$ ' with chromosome number of $2 n=4 x=52$; basic number of 13 are allotetraploid and autotetraploid, respectively, while parent $O$. canum ' $\mathrm{c}_{2}$ ' with chromosome number of $2 n=2 x=24$ and basic number of 12 is a diploid. The chromosomes of the Ocimum species are mainly metacentric and submetacentric with high symmetrical karyotypes. The high frequency of hybrid sterility observed was due to variation in chromosome sizes, numbers, and ploidy levels of the parents.

\section{ACKNOWLEDGEMENTS}

This study was supported by the Department of Botany of Obafemi Awolowo University, Ile-Ife, Nigeria, by providing necessary equipment and technical assistance.

\section{REFERENCES}

Albuquerque U.P., Andrade L.H.C., 1998: El genero Ocimum L. (Lamiaceae) en el nordeste del Brasil. - Anales Jardin Botanico Madrid, 56: 43-64.

Archna, Shivnaz, Neeraj T., Anand, 2013: Somatic chromosome studies in Ocimum basilicum and Ocimum sanctum L. - International Journal of Phytomedicine, 5: 330-340. 
Bentham G., 1848: Ocimum. - In: de Candolle A.P. (ed.), Prodromus Systematis Naturalis Regni Vegetabilis, 12: 31-44. - Paris.

Carovic-Stanko K., Liber Z., Besendorfer V., Javornik B., Bohanec B., Kolak I., Satovic Z., 2010: Genetic relations among basil taxa (Ocimum L.) based on molecular markers, nuclear DNA content, and chromosome number. - Plant Systematic and Evolution, 285: 13-22.

Darlington C.D., Wylie A.P., 1955: Chromosome Atlas of Flowering Plants. -London.

EDET O.U., AiKPOKPODION P.O., 2014: Karyotype analysis of Ocimum basilicum in South-Eastern Nigeria.American Journal of Plant Sciences, 5: 126-131.

Erum S., Naeemullah M., Masood S., Khan M.I., 2011: Genetic variation in the living repository of Ocimum germplasm, Pakistan. - Journal of Agricultural Research, 24(1-4): 42-50.

KhosLa M.K., 1988: Interspecific Hybridization in genus Ocimum involving the Species $O$. viride Willd. $(2 \mathrm{n}=40)$ and $O$. suave Willd. $(2 \mathrm{n}=48)$. Cytologia, 53: 37-44.

KhosLa M.K., 1989: Chromosome meiotic behaviour and ploidy nature in genus Ocimum (Lamiaceae), "Sanctum Group". - Cytologia, 54: 223-229.

Khosla M.K., Sовті S.N., 1985: Karyomorphological studies in genus Ocimum II. Sanctum group. Cytologia, 50: 253-263.

Larrosa F.H., Maune J.F., Erazzú L.E., Camadro E.L., 2011: Meiotic abnormalities underlying pollen sterility in wild potato hybrids and spontaneous populations. - Plant Biology, 14: 223-233.

Levan A., Fredga K., Sandberg A.A., 1964: Nomenclature for centromeric position on chromosomes. - Hereditas, 52: 201-220.

Liu Y., Hui R.K., Deng R.N., Wang J.J., Wang M., Li Z.Y., 2012: Abnormal male meiosis causes pollen sterility in medicinal polyploidy plant Pinellia ternate. - Genetics Molecular Research, 11: 112-120.

Löve Á. (ed.), 1980: IOPB chromosome number reports LXVI. - Taxon, 29(1): 163-169.

Menra P.N., Gill L.S., 1972: Cytology of west Himalayan Labiatae, tribe Ocimoideae. - Cytologia, 37: 53-57.

MorTON J.K., 1962: Cytotaxonomic studies in West African Labiatae. - Botanical Journal of the Linnean Society, 58: 231-263.
Mukherjee M., Datta A.K., 2006: Secondary Chromosome Associations in Ocimum spp. - Cytologia, 71(2): 149-152.

Mukherjee M., Datta A.K., Maiti G.G., 2005: Chromosome number variation in Ocimum basilicum L. - Cytologia, 70: 455-458.

Olorode O., 1974: Chromosome number in Nigeria. Compositae. - Botanical Journal of the Linnean Society, 68: 329-335.

Olorode O., Baquar S.R., 1976: The Hyparrhenia involucrata-H. subplumosa complex in Nigeria. Morphological and cytological characterization. - Botanical Journal of the Linnean Society, 72: 212-222.

Panda H., 2005: Cultivation of French basil (Ocimum basilicum L.) in Aromatic Plants Cultivation, Processing and Uses. - Delhi. (http://www. niir.org/books/book/aromatic-plants-cultivationprocessing-uses-h-panda/isbn-8178330571/).

Paton A., 1992: A synopsis of Ocimum L. (Labiatae) in Africa. - Kew Bulletin, 47: 403-435.

Paton A., Harley M.R., Harley M.M., 1999: Ocimum: an overview of classification and relationships. - In: Hiltunen R., Holm Y. (eds), Basil: the genus Ocimum: 1-38. - Amsterdam.

Paton A., Putievsky E., 1996: Taxonomic problems and cytotaxonomic relationships between varieties of Ocimum basilicum and related species (Labiatae). - Kew Bulletin, 51: 1-16.

Pushrangadan P., Bradu B.L., 1995: Basil. - In: Chadha K.L., Rajendra Gupta, (eds), Advances in Horticulture, 11, Medicinal and Aromatic Plants. - New Delhi.

Pushrangadan P., Sobti S.N., 1982: Cytogenetical studies in the genus Ocimum. 1. Origin of O. americanum, cytotaxonomical and experimental proof. - Cytologia, 47: 575-583.

RYDING O., 1994: Notes on the sweet basil and its wild relatives (Lamiaceae). - Economic Botany, 48: 65-67.

SingH T.P., 1978: Chromosome studies in Ocimum.Current Science, 47: 915-916.

Sobti S.N., Pushrangadan P., 1977: Cytotaxonomical studies in the genus Ocimum. - In: BIR S.S. (ed.), Taxonomy, Cytogenetics and Cytotaxonomy of Plants: 373-377. - New Delhi.

StebBins G.L., 1971: Chromosomal Evolution in Higher Plants. - London. 
Truta E., Zamfirache M.M., 2013: Preliminary cytogenetical investigation in two common basil varieties. - Analele Ştiinţifice ale Universităţii, Alexandru Ioan Cuza, Secţiunea Genetică şi Bio- logie Moleculară, 14: 29-34.

Vij S.P., Kashyap S.K., 1976: Cytological studies in some North Indian Labiatae. - Cytologia, 41: 713-719.

\section{DVIEJŲ OCIMUM (LAMIACEAE) RŪŠIU巳 IR JŲ F HIBRIDŲ MITOZĖS IR MEJOZĖS TY- RIMAI}

\section{Johnson Ademola Idowu, Matthew OzIEgBe}

\section{Santrauka}

Bazilikai (Ocimum L.) yra svarbūs aromatiniai ir vaistiniai augalai. Daug tyrinètoju yra pastebèję jų chromosomų skaičiaus ir ploidiškumo lygių kompleksiškumą. Mes tyrème Ocimum basilicum L. dviejų variantų O. canum Sims ('c $c_{1}$ ' ir ' $\mathrm{c}_{2}$ ') bei jų $F_{1}$ hibridų somatinių ir lytinių ląstelių chromosomų ypatybes ir elgseną. Šaknelių galiukų ir žiedinių pumpuru chromosomos buvo tiriamos standartiniais būdais; buvo sudaromos ir analizuojamos kariogramos. O. basilicum ir O. canum 'c 1 ' bei jų $\mathrm{F}_{1}$ hibridams nustatytas $2 \mathrm{n}=4 \mathrm{x}=52$ chromosomu skaičius. $O$. canum ' $\mathrm{c}_{2}$ ' variantas turejo $2 \mathrm{n}=2 \mathrm{x}=$ 24 chromosomas, o jo tarprūšinio hibrido $O$. canum
' $\mathrm{c}_{2}$ ' $\times$ O. canum ' $\mathrm{c}$ ' chromosomų skaičius buvo $2 \mathrm{n}$ $=38$. Šių Ocimum rūšių ir jų $\mathrm{F}_{1}$ hibridų kariotipų formulès skyrèsi, bet jų chromosomos dažniausiai buvo metacentrinès (174) bei submetacentrinès (36) ar žymiai rečiau subtelocentrinès (8). Remiantis chromosomų poravimosi konfigūracija, $O$. basilicum yra alotetraploidas, O. canum ' $\mathrm{c}_{1}$ ' - autotetraploidas, o O. canum ' $\mathrm{c}_{1}$ ' - diploidas. Mejoziniai nukrypimai dažniau stebèti $F_{1}$ hibriduose nei tèvuose. Tyrimas parodè vidurūšinị ir tarprūšinį chromosomų skaičiaus ir porų sudarymo varijavimą, tačiau centromeru padètis Ocimum rūšiu chromosomose buvo panaši. 